\title{
ANALISIS KEBUTUHAN TERHADAP MATERI PEMBELAJARAN INTRODUCTION TO LINGUISTICS BERBASIS E-LEARNING UNTUK MAHASISWA BAHASA INGGRIS
}

\author{
A. A. Sri Barustyawati ${ }^{1}$, N. L. P. Sri Adnyani ${ }^{2}$ \\ Jurusan Diploma Bahasa Inggris, Fakultas Bahasa dan Seni \\ Universitas Pendidikan Ganesha, Singaraja, Bali \\ E-mail: niluhputusriadnyani@gmail.com²
}

\begin{abstract}
This research is a need analysis of learning materials that need to be developed in the teaching of Introduction to Linguistics and the need for e-leaning. The data was obtained through questionnaires that contained opinions and assumpsions given to 25 students in the English Diploma III Department of Universitas Pendidikan Ganesha. Through this research, it is confirmed that students need knowledge in the field of linguistics and the need for e-learning. Of the five sub-fields of linguistics, phonetics, phonology, syntax, and semantics are considered very necessary. Whereas morphology is considered very much needed significantly. The need for morphology is at the level above other linguistic fields according to the results of the interviews where in mastering foreign languages there is a need for the mastery of broad vocabulary items. Words and word formation are part of the subject matter in the field of morphology. The results of this needs analysis also show the importance of e-learning in the learning process. The results of the questionnaires show that e-learning is in the very needed category. The importance of e-learning in Introductuion to Linguistics, one of which is the need to visualize learning material. Visualization of learning material provides an opportunity for learners to see real examples and not concepts that are too abstract. The results of this study are very useful in curriculum development and development of teaching materials. In addition, with the knowledge of learners'needs, the instructor can arrange material that is in accordance with the need to create an effective learning process.
\end{abstract}

Key words: need analysis, Introduction to Linguistics, e-learning

\begin{abstract}
ABSTRAK
Penelitian ini merupakan sebuah analisis kebutuhan terhadap materi-materi pembelajaran yang perlu dikembangkan dalam mata kuliah Introduction to Linguistics dan kebutuhan terhadap pembelajarn berbasis e-leaning pada mata kuliah tersebut. Data analisis kebutuhan diperoleh melalui kuestioner yang berisi tentang opini dan anggapan yang diberikan kepada 25 orang mahasiswa pada Jurusan Diploma III bahasa Inggris Universitas Pendidikan Ganesha. Melalui penelitian ini diperoleh kesimpulan bahwa mahasiswa membutuhkan pengetahuan di bidang linguistik dan kebutuhan akan perlunya pembelajaran linguistik melalui e-learning. Dari lima sub bidang linguistik, fonetik, fonologi, sintaksis, dan semantik dianggap sangat dibutuhkan. Sedangkan morfologi dianggap sangat dibutuhkan secara signifikan. Kebutuhan terhadap morfologi berada setingkat di atas bidang linguistik lainnya menurut hasil wawancara dengan informan diperoleh informasi bahwa untuk menguasai bahasa asing mereka memerlukan penguasaan kata-kata yang luas. Kata dan pembentukan kata merupakan bagian dari pokok bahasan di bidang morfologi. Hasil analisis kebutuhan ini juga memperlihatkan pentingnya e-learning dalam proses pembelajaran dengan hasil kuesioner yang menunjukkan bahwa e-learning berada dalam kategori sangat dibutuhkan. Pentingnya e-learning dalam pembelajaran Introductuion to Linguistics, salah satunya yakni perlunya visualisasi materi pembelajaran. Visualisasi materi pembelajaran memberikan kesempatan kepada pembelajar untuk melihat contoh-contoh secara nyata dan bukan konsep-konsep yang terlalu abstrak. Hasil penelitian ini sangat berguna dalam pengembangan kurikulum dan pengembangan bahan ajar. Di samping itu, dengan diketahuinya kebutuhan pembelajar, pengajar dapat menyusun materi yang sesuai dengan kebutuhan untuk menciptakan proses pembejaran yang efektif.
\end{abstract}

Kata kunci: analisis, kebutuhan, Introduction to Linguistics, e-learning 


\section{PENDAHULUAN}

Pembelajaran mata kuliah Introduction to Linguistics memiliki peran penting dalam perkuliahan di bidang bahasa. Prodi DIII Bahasa Inggris mencantumkan Introduction to Linguistics sebagai salah satu mata kuliah konten. Mata kuliah ini dimunculkan di semester III (tiga) berdasarkan KKNI 2016. Mata kuliah ini menyajikan berbagai topik yang berkaitan dengan materi linguistik. Muara akhir dari mata kuliah Introduction to Linguistics ini adalah mahasiswa memiliki pemahaman tentang fonetik, fonologi, morfologi, sintaksis, dan semantik serta mampu memecahkan persoalan-persolan yang berkaitan dengan lingkup kajian Introduction to Linguistics. Di samping itu, pembelajaran Introduction to Linguisticsjuga dapat menunjang keterampilan berbahasa Inggris mahasiswa.

Timyam (2008) berargumen bahwa kajian di bidang linguistik menunjukkan fakta-fakta empiris tentang bahasa manusia dan pemahaman yang lebih baik tentang sistem dalam suatu bahasa. Oleh karenanya, kajian linguistik diperkenalkan dalam pembelajaran bahasa Inggris. Timyam juga menjelaskan bahwa tujuan utama dari pengenalan linguistik kepada pembelajar yakni, untuk mendeskripsikan bahasa secara jelas, tepat, sistematis, dan konsisten dengan penggunaan yang sebenarnya, mempermudah pembelajar untuk belajar bahasa, untuk memahami sistem bahasa tersebut, dan mampu menganalisa, membandingkan dan mengkontraskan antar bahasa yang dipelajari dengan bahasa ibu mereka.

Hasil observasi pada semester ganjil 2017/2018 terhadap pembelajaran Introduction to Linguistics menunjukkan bahwa mahasiswa belum memiliki pemahaman konsep terhadap materi perkuliahan. Kemampuan mahasiswa terhadap beberapa permasalahan dalam pembelajaran Introduction to Linguistics masih cukup rendah. Pada awal pertemuan, peneliti selaku pengampu mata kuliah Introduction to Linguistics meminta mahasiswa untuk melakukan penelusuran pustaka baik di perpustakaan FBS Undiksha maupun secara daring untuk menemukan dan membaca materi-materi yang berhubungan dengan mata kuliah Introduction to Linguistics. Dengan mencari dan membaca berbagai sumber, mahasiswa diharapkan memiliki pemahaman dasar tentang materi yang dipaparkan. Namun, selama bulan pertama proses perkuliahan berlangsung pada bulan September 2017, buku ajar yang ditunjukkan oleh mahasiswa sebagai referensi belum dapat dipahami oleh mahasiswa secara baik. Buku-buku yang dibawa oleh mahasiswa kurang bisa dipahami oleh mahasiswa karena bahasa yang digunakan dalam buku-buku tersebut sangat tinggi sehingga mahasiswa semester tiga yang mendapat mata kuliah tersebut mengalami kesulitan dalam memahami buku-buku tersebut. Oleh karena itu, mahasiswa lebih banyak mencatat tentang informasi yang disampaikan oleh dosen dibandingkan dengan ikut terlibat dalam memberikan ulasan atau informasi dari materi yang mereka sudah baca. Dengan kata lain kemampuan mahasiswa untuk memahami buku-buku berbahasa Inggris tentang Introduction to Linguistics masih lemah.

Bercermin dari refleksi pelaksanaan pembelajaran pada semester ganjil tahun 2017/2018, lebih dari 70\% dari jumlah mahasiswa masih menganggap mata kuliah Introduction to Linguistics merupakan mata kuliah yang sulit. Hasil wawancara peneliti dengan mahasiswa juga menunjukkan bahwa mahasiswa mengalami kesulitan dalam memahami kajian Introduction to Linguistics karena belum memahami konsep dasar dari materi Introduction to Linguistics. Ketika pengampu mata kuliah menjelaskan materi, mereka paham namun cepat dilupakan. Mahasiswa sangat mengharapkan adanya bahan ajar yang dapat membimbing mahasiswa dalam perkuliahan. Jika ada bahan ajar dengan bahasa Inggris yang lebih mudah dipahami, mahasiswa meyakini dapat membaca dan memahami materi lebih awal sehingga mereka akan memiliki pengetahuan awal terkait dengan materi perkuliahan. Di samping itu, beberapa materi mata kuliah tersebut memerlukan visualisasi sehingga mahasiswa mengharapkan ada materi yang bisa mereka unduh secara 
daring. Dengan kata lain mereka membutuhkan perangkat elektronik atau pembelajaran menggunakan e-learning yang dapat menunjang keberhasilan proses pembelajaran mata kuliah tersebut.

Melihat peran penting pembelajaran Introduction to Linguistics pada program Diploma III Bahasa Inggris, maka perlu adanya proses pembelajaran yang efektif di Fakultas Bahasa dan Seni Universitas Pendidikan Ganesha, yakni pembelajaran yang relevan dengan kebutuhan mahasiswa dan mampu memberikan hasil yang bermakna bagi mahasiswa. Kajian linguistik adalah salah satu kajian yang sangat kompleks yang mencakup berbagai aspek kebahasaan. Oleh karena itu diperlukan suatu upaya untuk melihat dan menentukan mana aspek yang perlu ditekankan dan mana yang kurang perlu sehingga mata kuliah ini dapat menunjang keterampilan mahasiswa dalam berbahasa Inggris. Salah satu upaya untuk merealisasikannya adalah dengan menganalisa, memilah, menentukan, dan mengidentifikasi aspek-aspek yang menjadi materi ajar yang sesuai dengan kebutuhan mereka. Hal ini untuk memberi layanan belajar kepada mahasiswa yang lebih baik. Untuk mencapai hal tersebut diperlukan adanya suatu kajian yang menganalisis kebutuhan mahasiswa terhadap pembelajaran dan materi perkuliahan Introduction to Linguistics.

Menurut Graves (2000), analisis kebutuhan merupakan proses mengumpulkan informasi secara berkelanjutan tentang kebutuhan pembelajar, serta pilihan mereka, bagaimana menginterpretasi informasi yang diperoleh dan bagaimana membuat keputusan tentang pembelajaran yang akan dilaksanakan yang sesuai dengan kebutuhan pembelajar. Analisis kebutuhan dilakukan karena adanya keyakinan bahwa pembelajar tidak selalu serta merta menerima apa yang diajarkan, namun mereka bisa pula berpartisipasi dan menyumbang saran tentang apa yang mereka butuhkan dan ingin pelajari.

Hasil analisis kebutuhan ini sangat berguna untuk pengembangan kurikulum Jurusan Diploma III bahasa Inggris serta dalam pengembangan dan penyusunan materi ajar yang sesuai dengan kebutuhan pembelajar serta anggapan masiswa terhadap pentingnya penggunaan e-learning dalam pembelajaran Introduction to Linguistics. Dengan adanya bahan ajar yang sesuai dengan kebutuhan mahasiswa akan dapat memfasilitasi mahasiswa dalam belajar dan menolong mahasiswa untuk mencapai hasil belajar yang optimal.

\section{METODE}

Melalui penelitian ini, ingin diketahui kebutuhan mahasiswa dan dosen, permasalahan-permasalahan yang dihadapi mahasiswa dalam pembelajaran Introduction to Linguistics, dan materi-materi serta stategi yang tepat dalam pembelajaran mata kuliah tersebut. Subjek yang menjadi responden pada tahap ini adalah mahasiswa semester III Program Studi Bahasa Inggris Diploma III yang memprogram mata kuliah Introduction to Linguistics dan para dosen pada Program Studi Diploma III Bahasa Inggris, Undiksha. Rencana kegiatan diuraikan secara ringkas seperti pada tabel 1 berikut ini.

Tabel 1 : Rencana Kegiatan, dan Produk yang Diharapkan

\begin{tabular}{|c|c|c|c|}
\hline Tahun & Kegiatan Utama & Subjek & Produk \\
\hline $\begin{array}{l}\text { Tahun } \\
2018\end{array}$ & $\begin{array}{l}\text { 1. M e l a k u ka n } \\
\text { analisis kebutuh- } \\
\text { an (needs as- } \\
\text { sessment) mela- } \\
\text { lui studi lapangan. } \\
\text { Aspek-aspek yang } \\
\text { diselidiki pada } \\
\text { studi lapa-ngan } \\
\text { adalah sebagai } \\
\text { berikut. } \\
\text { a. Analisis kebu- } \\
\text { tuhan mahasiswa } \\
\text { terhadap mata ku- } \\
\text { liah Introduction } \\
\text { to Linguistics. } \\
\text { b. Analisis materi } \\
\text { mata kuliah In- } \\
\text { troduction to Li- } \\
\text { nguistics. }\end{array}$ & $\begin{array}{l}\text { Maha- } \\
\text { siswa } \\
\text { dan } \\
\text { dosen }\end{array}$ & $\begin{array}{l}\text { a. Deskripsi } \\
\text { kebutuhan } \\
\text { mahasiswa } \\
\text { dalam per- } \\
\text { kuliahan In- } \\
\text { trodution to } \\
\text { Linguistics } \\
\text { b. Deskripsi } \\
\text { berbagai } \\
\text { permasalah- } \\
\text { an yang } \\
\text { dihadapi } \\
\text { mahasiswa } \\
\text { dalam mata } \\
\text { kuliah Intro- } \\
\text { duction to } \\
\text { Linguistics. }\end{array}$ \\
\hline
\end{tabular}

Penelitian ini menggunakan metode dokumentasi, wawancara, dan penyebaran 
angket dalam pengumpulan data. Dengan metode tersebut, langkah-langkah yang akan ditempuh dalam penelitian ini adalah sebagai berikut. Pertama, mengobservasi kebutuhan mahasiswa di dalam mata kuliah Introduction to Linguistics dan mengedarkan angket kepada responden yang telah ditetapkan. Kedua, mentabulasikan dan menganalisis secara deskriptif kuantitatif jawaban mahasiswa. Ketiga, mengidentifikasi responden yang layak dijadikan informan. Keempat, mewawancarai informan yang telah ditetapkan dan mengumpulkan data dari dokumen. Kelima, mentranskripsikan hasil rekaman wawancara dan melakukan analisis terhadap data transkripsi secara induktif. Adapun jenis data, sumber data, dan teknik pengumpulan data disampaikan pada tabel 2 .

Tabel 2: Jenis Data, Sumber Data, dan Teknik Pengumpulan Data

\begin{tabular}{|c|c|c|}
\hline $\begin{array}{l}\text { Data yang } \\
\text { Diperlukan }\end{array}$ & $\begin{array}{c}\text { Sumber } \\
\text { Data }\end{array}$ & $\begin{array}{c}\text { Teknik } \\
\text { Pengumpulan } \\
\text { Data } \\
\end{array}$ \\
\hline $\begin{array}{l}\text { Kebutuhan akan } \\
\text { permasalahan } \\
\text { dan pemaham- } \\
\text { an mahasiswa } \\
\text { dalam mata } \\
\text { kuliah Introduc- } \\
\text { tion to Linguis- } \\
\text { tics }\end{array}$ & $\begin{array}{l}\text { Dosen } \\
\text { Mahasiswa }\end{array}$ & $\begin{array}{l}\text { Analisis } \\
\text { dokumen } \\
\text { Wawancara } \\
\text { angket }\end{array}$ \\
\hline
\end{tabular}

Data yang telah terkumpul diolah secara deskriptif kualitatif sehingga diperoleh simpulan tentang kebutuhan mahasiswa dan dosen dalam perkuliahan mata kuliah Introduction to Linguistics. Data dari hasil mengedarkan angket akan dianalisis secara kuantitatif-kualitatif. Sementara itu, data dari hasil wawancara dan pencatatan dokumen akan dianalisis secara kualitatif. Tahapan analisis dimulai dari mengidentifikasi hasil analisis kebutuhan, dokumentasi materi pembelajaran yang sesuai.

\section{HASIL DAN PEMBAHASAN}

Hasil penelitian yang akan dibahas dalam bagian ini adalah hasil analisis kebutuhan terhadap pentingnya materi pembelajaran Introduction to Linguistics dan pentingnya e-learning dalam mata kuliah ini. Dengan diketahuinya kebutuhan dalam mata kuliah ini selanjutnya akan disusun bahan ajar yang mencerminkan kebutuhan yang telah diperoleh dari hasil questionaire yang telah diberikan kepada mahasiswa.

\section{Hasil Analisis Kebutuhan terhadap Pemb- elajaran Introduction to Linguistics}

Pada bagian ini dibahas hasil kuesioner yang sudah disebar kepada 25 orang informan. Dalam kuesioner, informan diminta untuk menentukan skala terhadap masing-masing subtopik dalam pembelajaran Introduction to Linguistics sekaligus menentukan skala seberapa penting pembelajaran berbasis e-learning dalam mata kuliah tersebut. Adapun analisis kebutuhan ditentukan didasarkan pada lima skala Likert, yakni

Skala Kebutuhan pembelajaran linguistik

5 : paling dibutuhkan

4 : Sangat dibutuhkan

3 : cukup dibutuhkan

2 : sedikit dibutuhkan

1 : sangat sedikit dibutuhkan

Dalam menginterpretasi hasil analisis kebutuhan, kriteria yang digunakan adalah sebagai berikut:

$\begin{array}{ll}\text { Kisaran rata-rata } & \begin{array}{l}\text { Kategori/Makna } \\ \text { : Sangat dibutuhkan se- } \\ \text { cara signifikan }\end{array} \\ 3.21-5.00 & \text { : Sangat dibutuhkan } \\ 3.41-4.20 & \text { : Cukup dibutuhkan } \\ 2.61-3.40 & \text { : Sedikit dibutuhkan } \\ 1.81-2.60 & \text { : Paling sedikit dibutuh } \\ 1.00-1.80 & \text { kan }\end{array}$

\section{a. Kebutuhan Pembelajaran Fonetik}

Fonetik merupakan kajian tentang bunyi suatu bahasa. Dalam bidang fonetik, ada lima topik yang umumnya menjadi pembahasan, yakni transkripsi fonetik, cara pengucapan bunyi konsonan, cara pengucapan bunyi 
vokal, bunyi suprasegmental, dan bunyi bahasa selain bunyi bahasa Inggris. Hasil analisis kebutuhan terhadap pembelajaran fonetik dapat diamati melalui tabel 3 .

Tabel 3 Respon mahasiswa terhadap kebutuhan pembelajaran fonetik

\begin{tabular}{|l|c|c|c|}
\hline $\begin{array}{c}\text { Topik } \\
\text { di bidang } \\
\text { fonetik }\end{array}$ & Mean (M) & $\begin{array}{c}\text { Standar } \\
\text { Deviasi } \\
\text { (SD) }\end{array}$ & Rank \\
\hline $\begin{array}{l}\text { Transkrip- } \\
\text { si fonetis }\end{array}$ & 4.12 & 0.67 & 2 \\
\hline $\begin{array}{l}\text { Cara } \\
\text { penguca- } \\
\text { pan bunyi } \\
\text { konsonan }\end{array}$ & 4.36 & 0.7 & 1.5 \\
\hline $\begin{array}{l}\text { Cara } \\
\text { penguca- } \\
\text { pan bunyi } \\
\text { vokal }\end{array}$ & 4.36 & 0.81 & 1.5 \\
\hline $\begin{array}{l}\text { Bunyi } \\
\text { supraseg- } \\
\text { mental }\end{array}$ & 3.84 & 0.8 & 4 \\
\hline $\begin{array}{l}\text { Bunyi } \\
\text { bahasa } \\
\text { selain } \\
\text { bahasa } \\
\text { Inggris }\end{array}$ & 3.8 & 0.91 & 5 \\
\hline Total & 4.096 & 0.78 & N/A \\
\hline
\end{tabular}

Melalui analisis kebutuhan yang telah dilaksanakan ditemukan bahwa dari kelima topik tersebut, cara pengucapan bunyi konsonan dan cara pengucapan bunyi vokal menduduki posisi pertama dengan kategori sangat dibutuhkan secara signifikan $(\mathrm{M}=4.36)$. Dalam topik cara pengucapan bunyi konsonan, dibahas bunyi-bunyi konsonan yang terdapat dalam bahasa Inggris dan bagaimana cara mengucapkan bunyi-bunyi tersebut. Begitu pula halnya dengan cara pengucapan bunyi vokal ditekankan bunyi-bunyi vokal yang terdapat dalam bahasa Inggris dan bagimana cara memproduksi bunyi-bunyi tersebut melalui alat ucap. Bahwa cara pengucapan bunyi konsonan dan bunyi vokal memiliki rata-rata tertinggi dalam analisis kebutuhan ini dapat dimengerti mengingat beberapa bunyi konsonanan yang terdapat dalam bahasa Inggris tidak ditemukan dalam bahasa Indonesia sehingga dapat mengarah pada kesalahan pengucapan (Andi-pallawa, 2013; Habibi, 2016; Mathew, 2005; Tiono \& Yostanto, 2008). Disamping itu, cara mengeja dalam bahasa Inggris berbeda dengan cara pengucapannya. Hal ini juga ditemukan pada beberapa bunyi vokal (Yuniarti, 2009). Oleh karena, itu responden menganggap bahwa kedua topik di atas sangat dibutuhkan secara signifikan.

Untuk topik transkripsi fonetis berada pada kategori sangat dibutuhkan $(\mathrm{M}=4.12)$. Topik ini berhubungan dengan merepresentasikan bunyi-bunyi melalui simbol-simbol fonetis. Melalui topik ini juga dibahas tentang cara dan tempat artikulasi, serta posisi bunyi-bunyi tersebut dalam tabel International Phonetics Alphabet (IPA). Begitu pula dengan simbol-simbol bunyi vokal dalam bahasa Inggris diperkenalkan dan dapat dipahami tentang tinggi rendahnya vokal serta bagian lidah mana yang bertanggung jawab terhadap produksi bunyi-bunyi vokal tersebut.

Melalui analisis kebutuhan ini, topik bunyi suprasegmental menduduki posisi keempat dalam pembelajaran fonetik $(\mathrm{M}=3.84)$, yakni dengan kategori sangat dibutuhkan. Dalam topik bunyi suprasegmental ditekankan pola penggunaan tekanan dan intonasi. Topik ini dipandang sangat dibutuhkan mengingat bahasa Inggris memiliki posisi penekanan kata yang berbeda-beda dan bahkan perbedaan posisi penekanan kata dapat mengakibatkan perbedaan kategori kata (Wickham, 2012). Sedangkan dalam bahasa Indonesia posisi penekanan pada kata tidak mengakibatkan perubahan kategori kata (Alwi, Dardjowidjojo, Lapoliwa, \& Moeliono, 2003). Intonasi dalam bahasa Inggris juga sangat dibutuhkan karena intonasi sangat penting dalam menyampaikan makna pembicara.

Topik yang memiliki skor rata-rata paling rendah dalam pembelajaran fonetik adalah perlunya mempelajari bunyi bahasa selain bunyi bahasa Inggris $(\mathrm{M}=3.8)$. Namun demikian, topik ini berada dalam kategori sangat dibutuhkan. Artinya, responden menganggap pemahaman bunyi-bunyi bahasa lain dianggap perlu untuk dipahami. Salah satunya, yakni 
bunyi-bunyi bahasa yang terdapat dalam bahasa Indonesia. Dengan pengetahuan ini mahasiswa dapat melakukan analisis kontrastif terhadap bunyi-bunyi yang terdapat dalam bahasa pertama mereka dengan bunyi-bunyi dalam bahasa target yang mereka pelajari.

\section{b. Kebutuhan Pembelajaran Fonologi}

Dalam pembelajaran fonologi, ada tiga topik yang didiskusikan dalam penelitian ini, yakni cara membedakan fonem dan alofon, aturan fonologis, dan analisis fonologis. Adapun hasil dari analisis kebutuhan terhadap ketiga topik tersebut dapat diamati pada tabel 4.

Tabel 4. Respon mahasiswa terhadap kebutuhan pembelajaran fonologi

\begin{tabular}{|l|c|c|c|}
\hline $\begin{array}{c}\text { Topik di } \\
\text { bidang } \\
\text { fonologi }\end{array}$ & Mean (M) & $\begin{array}{c}\text { Standar } \\
\text { Deviasi } \\
\text { (SD) }\end{array}$ & Rank \\
\hline $\begin{array}{l}\text { Cara mem- } \\
\text { bedakan } \\
\text { fonem dan } \\
\text { alofon }\end{array}$ & 3.76 & 0.88 & 3 \\
\hline $\begin{array}{l}\text { Phonologi- } \\
\text { cal rules }\end{array}$ & 4.16 & 0.67 & 1 \\
\hline $\begin{array}{l}\text { Phonologi- } \\
\text { cal analysis }\end{array}$ & 4.12 & 0.6 & 2 \\
\hline Total & 4.013 & 0.73 & N/A \\
\hline
\end{tabular}

Pada tabel 4 dapat dilihat bahwa aturan fonologis dalam bahasa Inggris menduduki posisi paling dibutuhkan secara signifikan dengan $(\mathrm{M}=4.16)$. Aturan fonologis mencakup pembahasan-pembahasan yang berkaitan dengan bagaimana sistem yang mengatur proses keluarnya bunyi. Selanjutnya, topik yang dianggap sangat dibutuhkan dalam pembelajaran folologi adalah analisis fonologis $(\mathrm{M}=$ 4.12). Analisis terhadap proses-proses fonologis yang terjadi dalam suatu bahasa sangatlah penting. Terjadinya proses fonologis bahkan dapat dilihat pada perkembangan bahasa anak (Adnyani \& Pastika, 2016). Dapat pula dikatakan bahwa proses fonologis bisa terjadi pada pembelajar bahasa sebagai bahasa asing. Adapun topik yang mendapat skor rata-rata terendah adalah cara membedakan fonem dan alofon $(M=3.76)$. Fonem merupakan bunyibunyi yang dapat membedakan makna. Sedangkan alofon merupakan pembedaan realisasi bunyi dari sebuah fonem (Alwi et al., 2003).

\section{c. Kebutuhan Pembelajaran Morfologi}

Menurut Verhaar (2008) morfologi merupakan cabang ilmu linguistik yang mengidentifikasi satuan-satuan dasar bahasa sebagai satuan gramatikal. Dalam pembelajaran morfologi, ada tiga topik yang menjadi pokok bahasan, yakni elemen morfologi, proses morfologi, dan sistem morfologi. Hasil analisis kebutuhan pada aspek morfologi ditampilkan melalui Tabel 5 .

Tabel 5. Respon mahasiswa terhadap kebutuhan pembelajaran morfologi

\begin{tabular}{|l|c|c|c|}
\hline $\begin{array}{c}\text { Topik di } \\
\text { bidang } \\
\text { morfologi }\end{array}$ & Mean (M) & $\begin{array}{c}\text { Standar } \\
\text { Deviasi } \\
\text { (SD) }\end{array}$ & Rank \\
\hline $\begin{array}{l}\text { Elemen } \\
\text { morfologi }\end{array}$ & 4.24 & 0.72 & 3 \\
\hline $\begin{array}{l}\text { Proses } \\
\text { morfologi }\end{array}$ & 4.28 & 0.79 & 1.5 \\
\hline $\begin{array}{l}\text { Sistem } \\
\text { morfologi }\end{array}$ & 4.28 & 0.74 & 1.5 \\
\hline Total & 4.267 & 0.75 & N/A \\
\hline
\end{tabular}

Pada Tabel 5 dapat diamati bahwa proses morfologi dan sistem morfologi menduduki posisi paling atas masing-masing dengan $(\mathrm{M}=4.28)$ dengan kategori, yakni sangat dibutuhkan secara signifikan. Aspek morfologi sangat penting dalam perkembangan bahasa dan merupakan salah satu aspek dimana pengaruh lintas bahasa bisa terjadi dalam proses pemerolehan suatu bahasa (Adnyani, Beratha, Pastika, \& Suparwa, 2018). Topik elemen morfologi juga memiliki kategori sebagai topik yang sangat dibutuhkan secara signifikan $(\mathrm{M}=4.24)$. Dalam topik elemen morfologi, dibahas tentang morfem dan melihat kata yang dibentuk dalam bahasa Inggris terdiri atas morpheme apa saja.

\section{d. Kebutuhan Pembelajaran Sintaksis}

Sintaksis merupakan tatabahasa yang 
melihat hubungan antar-kata dalam kalimat atau tuturan. Sintaksis mengatur bagaimana kata-kata dirangkai menjadi frasa dan bagimana frasa disusun menjadi sebuah kalimat. Pada bagian pembelajaran sintaksis, ada empat topik yang menjadi pokok bahasan, yakni kategori sintaksis, fungsi sintaksis, kategori frasa, dan analisa kalimat. Adapun hasil analisis kebutuhan terhadap materi pembelajaran sintaksis dapat diamati pada tabel 6 .

Tabel 6. Respon mahasiswa terhadap kebutuhan pembelajaran sintaksis

\begin{tabular}{|l|c|c|c|}
\hline $\begin{array}{c}\text { Topik di } \\
\text { bidang } \\
\text { sintaksis }\end{array}$ & Mean (M) & $\begin{array}{c}\text { Standar } \\
\text { Deviasi } \\
\text { (SD) }\end{array}$ & Rank \\
\hline $\begin{array}{l}\text { Katagori } \\
\text { sintaksis }\end{array}$ & 3.88 & 0.53 & 4 \\
\hline $\begin{array}{l}\text { Fungsi } \\
\text { sintaksis }\end{array}$ & 4.12 & 0.73 & 2 \\
\hline $\begin{array}{l}\text { Katagori } \\
\text { frasa }\end{array}$ & 4.08 & 0.70 & 3 \\
\hline $\begin{array}{l}\text { Analisa } \\
\text { Kalimat }\end{array}$ & 4.44 & 0.65 & 1 \\
\hline Total & 4.13 & 0.66 & N/A \\
\hline
\end{tabular}

Pada tabel 6 dapat diamati bahwa materi analisa kalimat menempati posisi paling atas dengan $\mathrm{M}=4.44$ dengan kategori sangat dibutuhkan secara signifikan. Materi selanjutnya, yakni fungsi sintaksis $\mathrm{M}=4.12$ dengan kategori sangat dibutuhkan. Dalam materi fungsi sintaksis dilihat apakah sebuah kata atau frasa berfungsi sebagai subjek, predikat atau objek. Materi selanjutnya, yakni kategori frasa didapatkan $M=4.08$ dengan kategori sangat dibutuhkan. Sedangkan dalam kategori sintaksis dilihat apakah sebuah kata dalam tuturan memiliki kategori sebagai nomina, verba, adjektiva, adverbia, preposisi, ataupun kategori yang lainnya (Alwi et al., 2003). Dari analisis kebutuhan yang telah dilakukan, kategori sintaksis didapatkan rata-rata dengan $\mathrm{M}=$ 3.88 juga dianggap sebagai topik yang sangat dibutuhkan.

Pembelajaran sintaksis sangat dibutuhkan oleh mahasiswa bahasa Inggris. Hal ini juga untuk memberikan gambaran bagaimana struktur bahasa target. Dengan diketahuinya struktur bahasa target bisa meminimalisir kesalahan mahasiswa dalam menyusun dan menggunakan kalimat dalam bahasa Inggris. Bagaimana struktur bahasa pertama dalam hal ini bahasa Indonesia dapat mempengaruhi struktur dalam bahasa target, yakni bahasa Inggris diulas oleh Fauziati (2017).

\section{e. Kebutuhan Pembelajaran Semantik}

Semantik merupakan cabang ilmu linguistik yang membahas arti atau makna. Dalam pembelajaran semantik, ada lima topik yang menjadi pokok bahasan, yakni denotasi dan konotasi, relasi semantik, fitur semantik, metafora, dan interpretasi kalimat. Hasil studi analaisis kebutuhan terhadap pembelajaran semantik dapat diamati melalui tabel 7.

Tabel 7 Respon mahasiswa terhadap kebutuah pembelajaran semantik

\begin{tabular}{|c|c|c|c|}
\hline $\begin{array}{c}\text { Topik } \\
\text { semantik }\end{array}$ & Mean (M) & $\begin{array}{c}\text { Standar } \\
\text { Deviasi } \\
\text { (SD) }\end{array}$ & Rank \\
\hline $\begin{array}{l}\text { Deno- } \\
\text { tasi dan } \\
\text { konotasi }\end{array}$ & 4.32 & 0.69 & 1 \\
\hline $\begin{array}{l}\text { Relasi } \\
\text { semantik }\end{array}$ & 4.04 & 0.68 & 5 \\
\hline $\begin{array}{l}\text { Fitur se- } \\
\text { mantik }\end{array}$ & 4.16 & 0.55 & 3.5 \\
\hline Metafora & 4.16 & 0.62 & 3.5 \\
\hline $\begin{array}{l}\text { Inter- } \\
\text { pretasi } \\
\text { kalimat }\end{array}$ & 4.2 & 0.76 & 2 \\
\hline Total & 4.176 & 0.67 & N/A \\
\hline
\end{tabular}

Pada tabel 7 dapat diamati bahwa secara umum bahwa semantik sangat dibutuhkan dalam pembelajaran bahasa Inggris dengan $M=4.176$. Dari lima topik yang menjadi pokok bahasan dalam pembelajaran semantik denotasi dan konotasi menempati posisi paling atas dengan $\mathrm{M}=4.32$ dengan kategori sangat dibutuhkan secara signifikan. Menurut (Verhaar, 2008b) denotasi merupakan referensi pada sesuatu yang ekstralingual menurut makna kata yang bersangkutan. Sedang- 
kan konotasi mengacu pada 'arti' yang dapat muncul pada penutur akibat penilaian afektif atau emosional. Keempat materi lain, yakni relasi semantik, fitur semantik, metafora, dan interpretasi kalimat memiliki rata-rata yang hampir sama dengan kategori sangat dibutuhkan. Dalam relasi semantik dilihat hubungan makna antara satuan bahasa yang satu dengan satuan bahasa yang lainnya. Dalam relasi semantik hubungan satuan bahasa dapat berupa sinonim, antonim, homonim, dan hiponim. Fitur semantik membahasa tentang penendapenanda semantik. Metafora merupakan gaya bahasa yang membandingkan sesuatu dengan yang lainnya yang juga disebut dengan majas. Sedangkan interpretasi kalimat membahas tentang bagaimana menafsirkan, menjelaskan atau memaknai kalimat tentang suatu objek yang didasari pada pemikiran mendalam dan dapat dipengaruhi oleh latar belakang atau pengalaman subjek.

\section{f. Kebutuhan Pembelajaran Berbasis E- Learning}

Mengingat bahwa mata kuliah Introduction to Linguistics merupakan mata kuliah konten yang diharapkan dapat mengikuti perkembangan teknlogi, dalam kajian analisis kebutuhan ini juga disertakan pertanyaan yang berhubungan dengan pentingnya pembelajaran berbasis e-learning. Respon mahasiswa terhadap pentingnya pembelajaran berbasis $e$ learning dapat diamati pada tabel 8 .

Tabel 8. Respon mahasiswa terhadap kebutuhan pembelajaran berbasis e-learning

\begin{tabular}{|l|c|c|c|}
\hline $\begin{array}{l}\text { Topics in } \\
\text { semantics }\end{array}$ & Mean (M) & $\begin{array}{c}\text { Standar } \\
\text { Deviasi } \\
\text { (SD) }\end{array}$ & Rank \\
\hline $\begin{array}{l}\text { Pembela- } \\
\text { jaran } e- \\
\text { learning }\end{array}$ & 4.24 & 0.88 & 1 \\
\hline Total & 4.24 & 0.88 & N/A \\
\hline
\end{tabular}

Pada tabel 8 tertera bahwa pembelajaran Introduction to Linguistics dianggap sebagai pembelajaran dimana pembelajaran dengan e-learning sangat dibutuhkan secara signifikan. Menurut Thinh (2016) pembelajaran menggunakan teknologi sangatlah penting dalam dunia pendidikan saat ini yang dapat mendukung dan menambah kualitas pembelajaran. Pembelajaran berbasis e-learning melibatkan partisipasi pengajar dan pembelajaran untuk memperbaharui aktivitas atau proses belajar mengajar yang dilakukan. Hassan (2007) mengajukan beberapa keuntungan dalam menggunakan tehnologi dan materi pembelajaran di tingkat universitas, yakni 1) proses pembelajaran yang lebih aktif, 2) metode pembelajaran yang beragam, 3) perhatian and kepedulian pembelajar yang lebih baik, 4) menejemen waktu oleh pengajar yang lebih efektif, 5) adanya simulasi secara visual. Di samping itu pembelajaran menggunakan $e$ learning memiliki fleksibilitas dan kemampuan dalam menutupi jarak.

Dalam pembelaran Introduction to Linguistics visualisasi materi pembelajaran sangatlah penting. Visualisasi sangat dibutuhkan baik melalui audio maupun video, misalnya dalam memperkenalkan bagaimana segmen-segmen bunyi disuarakan. Melalui e-learning, materi contoh-contoh penyuaraan segmen-segmen bunyi dapat diunggah dan diunduh oleh pembelajar. Mereka bisa mengunduh materi kapanpun mereka memerlukannya serta mendengar dan melihat serta menirukan bagaimana cara memproduksi bunyi bahasa secara benar secara berulang-ulang sesuai dengan kebutuhan mereka. Tanpa visualisasi, ada beberapa materi pembelajaran yang sangat abstrak yang kemungkinan sulit untuk dibayangkan oleh pembelajar. Oleh karena itu, e-learning memberikan kesempatan kepada pembelajar untuk menggunakan perangkat elektronik seperti komputer, laptop maupun smartphone sebagai alat untuk menunjang kelancaran dan kesuksesan proses pembelajaran.

\section{SIMPULAN}

Penelitian ini merupakan sebuah penelitian pengembangan bahan ajar mata kuliah Introduction to Linguistics yang diawali dengan analisis kebutuhan terhadap materi- 
materi pembelajaran yang perlu dikembangkan dalam mata kuliah tersebut. Data analisis kebutuhan diperoleh melalui questioner yang berisi tentang opini dan anggapan yang diberikan kepada 25 orang mahasiswa pada Jurusan Diploma III Bahasa Inggris .

Melalui penelitian ini diperoleh kesimpulan bahwa mahasiswa membutuhkan pengetahuan di bidang linguistik dan kebutuhan akan perlunya pembelajaran linguistik melalui e-learning. Dari lima sub bidang linguistik, fonetik, fonologi, sintaksis, dan semantik dianggap sangat dibutuhkan. Sedangkan morfologi dianggap sangat dibutuhkan secara signifikan. Kebutuhan terhadap morfologi berada setingkat di atas bidang linguistik lainnya menurut hasil wawancara dengan informan diperoleh informasi bahwa untuk menguasai bahasa asing mereka memerlukan penguasaan katakata yang luas. Kata dan pembentukan kata merupakan bagian dari pokok bahasan di bidang morfologi.

Hasil penelitian juga menunjukkan pentingnya disusun bahan ajar Introduction to Linguistics yang khusus ditujukan untuk mahasiswa bahasa Inggris Diploma III. Bahan ajar yang disusun hendaknya secara praktis dapat meningkatkan keterampilan mahasiswa dalam berbahasa Inggris. Dengan kata lain, materi ajar mengandung latihan-latihan berbahasa dan bukan mengandung hal-hal teoretis atau konsep-konsep abstrak yang sulit untuk diaplikasikan oleh mahasiswa.

Hasil analisis kebutuhan ini juga memperlihatkan pentingnya e-learning dalam proses pembelajaran dengan hasil kuesioner yang menunjukkan bahwa e-learning berada dalam kategori sangat dibutuhkan. Pentingnya e-learning dalam pembelajaran Introduction to Linguistics, salah satunya yakni perlunya visualisasi materi pembelajaran. Visualisasi materi pembelajaran memberikan kesempatan kepada pembelajar untuk melihat contohcontoh secara nyata dan bukan konsep-konsep yang terlalu abstrak.

\section{DAFTAR PUSTAKA}

Adnyani, N. L. P. S., Beratha, N. L. S., Pastika, I. W., \& Suparwa, I. N. 2018. The Development of Verbal Morphology And Word Order In An IndonesianGerman Bilingual Child: A Case Study. Topics in Linguistics, 19(67), 33-53.

Adnyani, N. L. P. S., \& Pastika, I. W. 2016. Phonological Development in the Early Speech of an Indonesian-German Bilingual Child. Research in Language, 14(3), 329-350. https://doi.org/10.1515/ rela-2016-0017

Alwi, H., Dardjowidjojo, S., Lapoliwa, H., \& Moeliono, A. M. 2003. Tata Bahasa Baku Bahasa Indonesia. Jakarta: Balai Pustaka.

Andi-pallawa, B. 2013. A Comparative Analysis between English and Indonesian Phonological Systems. International Journal of English Language Education, 1(3), 103-129. https://doi.org/10.5296/ijele.v1i 3.3892

Fauziati, E. F. 2017. Native and Target Language Influence on the Students' Interlanguage Production: a Case of Indonesian Efl Compositions. Indonesian Journal of Applied Linguistics, 7(1), 54. https://doi.org/10. 17509/ijal.v7i1.6858

Graves, K. 2000. Designing Language Courses: A Guide For Teachers. Boston: Heinle \& Heinle.

Habibi,M.W.2016.English Pronunciation Problems Encountered by Indonesian Advanced Students. THESIS. Maulana Malik Ibrahim StateIslamicUniversityofMalang,Malang. Retrieved from http://etheses.uin-malang. ac.id/4094/1/12320063.pdf

Hassan, M. S. 2007. Critical Success FacTors For E-Learning Acceptence. Elsevier Computers\& Education, 49, 396-413.

Mathew, I. 2005. Errors In Pronunciation Of Consonants By Learners Of English As A Foreign Language Whose First Languages Are Indonesian, Gayo And Acehnese. Monash University Linguistics Papers, 3(2), 29-44.

Thinh, D. Van. 2016. The Role of E-learning. In Management, Enterprise, and Bench Marking In The 21St Century (pp.239250).

Budapest. Timyam, N. 2008. Needs Analysis 
of Knowledge in Linguistics for EnglishMajor Students. Kasetsart J. (Soc.Sci), 292, 279-292.

Tiono, N. I., \& Yostanto, A. M. 2008a. Study of English Phonological Errors Produced By English Department Students. K@Ta, 10(1), 79-112. https://doi.org/ 10.9744/kata.10.1.79-112.

Verhaar, J. W. M. 2008a. Asas-Asas Linguistik Umum. Yogyakarta: Gadjah Mada University Press.

Verhaar, J. W. M. 2008b. Asas-asas Linguistik Umum. Yogyakarta: Gadjah Mada University Press.

Wickham, R. 2012.Stress and Intonation InEnglish. Kota Bharu: Brighton Education Learning Services.

Yuniarti, D. A. Y. U. 2009. A Study On The Pronounciation of English Vowels By The English Department Students,. School of Teacher Training and Education Muhammadiyah University of Surakarta. 